\title{
Karakteristik Sensori, Kimia dan Fisik Pempek dari Ikan Tenggiri dan Ikan Kiter Pada Berbagai Formulasi
}

\section{Sensory, Chemical and Physical Characteristic of Pempek from Barred Mackerel and Barracuda Fish in Various Formulations}

\author{
Esa Ghanim Fadhallah ${ }^{1 *}$, Fibra Nurainy ${ }^{1}$, dan Erdi Suroso ${ }^{1}$ \\ ${ }^{1}$ Jurusan Teknologi Hasil Pertanian, Fakultas Pertanian, Universitas Lampung \\ *E-mail: esa.ghanim@fp.unila.ac.id
}

\begin{abstract}
Pempek is one of the traditional snack food from Palembang which is made from fish and very popular in Indonesia. The objective of this study was to determine the effect of the combination of barred mackerel fish and pick handle barracuda fish meat on sensory, chemical, and physical properties and to determine the best economic formulation of pempek. This study used the Completely Randomized Design with six-level treatments of a combination of barred mackerel fish and pick handle barracuda fish, respectively, $200 \mathrm{~g}-0 \mathrm{~g}$ (P1), $160 \mathrm{~g}-40 \mathrm{~g}$ (P2), $120 \mathrm{~g}-80 \mathrm{~g}$ (P3), $80 \mathrm{~g}-120 \mathrm{~g}$ (P4), $40 \mathrm{~g}-160 \mathrm{~g}$ (P5), and $0 \mathrm{~g}$-200 $\mathrm{g}$ (P6). The characteristics of pempek were observed on the sensory (color, aroma, taste, texture, and overall acceptance), chemical (moisture and protein content), and physical properties (hardness, cohesiveness, springiness). The result showed that the treatment only has a significant effect on the color parameter of sensory properties. The higher amount of use of pick handle barracuda fish significantly reduced the panelist preference on color. The best formulation chosen was the combination of $40 \mathrm{~g}$ barred mackerel fish and $160 \mathrm{~g}$ pick handle barracuda with an economic total raw material cost of $R p$ 12.750. This formulation is recommended to produce pempek with the best quality and economic cost.
\end{abstract}

Keywords: economic, formulation, pempek, sensory properties

Disubmit : 2 Maret 2021; Diterima: 27 Maret 2021; Disetujui : 14 April 2021

\section{PENDAHULUAN}

Pempek merupakan cemilan khas dari Provinsi Sumatera Selatan, khususnya Palembang, dengan tekstur yang kenyal dan dilengkapi kuah "cuko" yang memiliki cita rasa yang khas. Makanan ini sudah sangat terkenal sehingga mudah dijumpai hampir di seluruh kota di Indonesia. Pempek berbahan dasar daging ikan yang dilumatkan dan dicampur dengan bahan lain seperti tepung tapioka sebaagai bahan pengikat, garam sebagai pemberi cita rasa, air sebagai media pelarut garam dan bawang putih sebagai penyedap aroma (Karneta et al. 2013, Sari et al. 2016). Campuran bahan tersebut menghasilkan cita rasa gurih dan tekstur yang kenyal pada pempek. Karakteristik tersebut menjadikan pempek sebagai salah satu makanan yang cukup favorit di Indonesia.

Jenis ikan yang sering digunakan di Palembang sebagai bahan utama pembuatan pempek adalah ikan belida. Namun untuk di wilayah lain, ikan jenis ini sulit untuk didapatkan dan harganya cukup mahal, sehingga diperlukan alternatif ikan lain yang dapat menggantikan ikan belida dalam pembuatan pempek. Berbagai jenis ikan telah banyak digunakan dalam pembuatan pempek seperti tenggiri (Alhanannasir et al. 
2018), cakalang (Talib \& Marlena 2015), belut (Rofiq \& Ernawati 2017), gabus (Sugito \& Hayati 2006), dan lele (Aminullah et al. 2020). Ikan tenggiri (Scomberomorus commersonii) merupakan jenis ikan laut ekonomis yang mudah ditemukan hampir di seluruh kota di Indonesia. Ikan ini memiliki daging dengan cita rasa gurih dan warna yang putih cerah sehingga cocok untuk dimanfaatkan dalam pembuatan pempek. Tenggiri juga memiliki rendemen daging yang tinggi yaitu 57,23-58,57\% (Maulid and Nurilmala 2015) sehingga cukup dipertimbangkan sebagai alternatif pengganti ikan belida dalam pembuatan pempek. Namun dibalik kelebihannya tersebut, di pasaran saat ini ikan tenggiri merupakan komoditas hasil laut dengan harga yang cukup mahal sehingga harga pempek yang dijual juga mahal. Pelaku usaha pempek dapat menggunakan kombinasi ikan tenggiri dengan ikan lain untuk menurunkan biaya produksi. Jenis ikan yang cocok untuk dikombinasikan dengan ikan tenggiri dalam pembuatan pempek adalah ikan kiter.

Ikan kiter (Sphyraena jello) merupakan jenis ikan laut hasil tangkap samping yang juga banyak ditemukan. Ikan kiter juga dilaporkan memiliki rendemen daging yang cukup tinggi yaitu 51,07\% dengan kandungan asam amino yang dapat memberikan cita rasa gurih (Jacoeb et al. 2018). Oleh karena itu, ikan kiter cocok untuk dikombinasikan dengan ikan tenggiri selain bertujuan untuk menghasilkan pempek dengan berkualitas juga untuk menyiasati harga bahan baku yang tinggi dari ikan tenggiri. Namun belum ada penelitian yang melaporkan mengenai kombinasi penggunaan daging ikan tenggiri dan ikan kiter dalam pembuatan pempek dan data karakteristik yang dihasilkan. Selain itu perlu adanya perhitungan ekonomi dari biaya bahan baku yang dapat dijadikan pertimbangan untuk usaha pempek dengan produk yang berkualitas dan harga yang ekonomis. Berdasarkan hal tersebut, maka penelitian karakteristik sensori, kimia dan fisik pempek dengan penggunaan daging ikan kiter dan ikan tenggiri menjadi penting untuk dilakukan.

Penelitian ini bertujuan untuk mengetahui karakteristik sensori, kimia dan fisik pempek dari ikan tenggiri dan ikan kiter, mengetahui pengaruh variasi penggunaan daging ikan tenggiri dan ikan kiter terhadap karakteristik sensori, kimia dan fisik pempek dan menentukan formulasi terbaiknya dari sisi ekonomi.

\section{METODE PENELITIAN}

Bahan dan Alat. Penelitian dilaksanakan pada bulan Juni hingga September 2020, yang bertempat di Laboratorium Pengolahan Hasil Pertanian, Jurusan Teknologi Hasil Pertanian, Fakultas Pertanian, Universitas Lampung. Bahan utama yang digunakan dalam penelitian ini adalah ikan kiter dan ikan tenggiri segar yang dibeli dari Pasar Ikan Gudang Lelang, Bandar Lampung. Bahan lain yang digunakan dalam pembuatan pempek diantaranya garam, tapioka (merk Sagu Tani) dengan rasio amilosa:amilopektin sebesar $20.12 \%: 71.03 \%$, dan air. Alat yang digunakan dalam pembuatan pempek diantaranya food processor (merk Quatre model OLL-688), timbangan digital (merk JOIL model D2) pisau, spatula, wadah plastik, panci dan kompor. Peralatan lain yang digunakan diantaranya peralatan kimia untuk analisis kadar air dan kadar protein, Texture Analyzer (merk Brookfield model CT-3) untuk analisis karakteristik fisik (hardness, springiness, dan cohesiveness) dan uji sensori (score sheet uji sensori, piring, dan garpu).

Prosedur Penelitian. Penelitian ini menggunakan Rancangan Acak Lengkap (RAL) menggunakan enam taraf perlakuan yaitu variasi penggunaan daging ikan tenggiri dan ikat kiter dengan tiga kali pengulangan. Pembuatan pempek diawali dengan pengambilan bagian daging pada tubuh ikan. Daging yang sudah dipisahkan dari kulit dan tulang selanjutnya dicuci bersih hingga bebas dari kotoran. Daging ikan tenggiri dan ikan kiter selanjutnya dilumatkan terlebih dahulu yang selanjutnya digunakan dalam formulasi pembuatan pempek yang tersaji pada Tabel 1 .

Daging ikan yang sudah lumat dicampurkan dengan garam dan air es pada wadah plastik dan diaduk hingga rata. Tepung tapioka selanjutnya dimasukkan ke dalam wadah dan diaduk kembali hingga adonan rata. Adonan selanjutnya dibentuk menjadi bentuk lenjer (panjang $\pm 10 \mathrm{~cm}$, lebar $\pm 3 \mathrm{~cm}$ ) dan direbus dalam air mendidih (suhu $100{ }^{\circ} \mathrm{C}$ ) selama 10 menit. 
Tabel 1. Formulasi pempek dengan perlakuan variasi daging ikan tenggiri dan ikan kiter

\begin{tabular}{cccccc}
\hline Perlakuan & Ikan tenggiri (gram) & Ikan kiter (gram) & Tapioka (gram) & Garam (gram) & Air (ml) \\
\hline P1 & 200 & 0 & 150 & 8 & 150 \\
P2 & 160 & 40 & 150 & 8 & 150 \\
P3 & 120 & 60 & 150 & 8 & 150 \\
P4 & 80 & 120 & 150 & 8 & 150 \\
P5 & 40 & 160 & 150 & 8 & 150 \\
P6 & 0 & 200 & 150 & 8 & 150 \\
\hline
\end{tabular}

Pempek yang sudah matang selanjutnya ditiriskan dan dipersiapkan untuk dilakukan analisis karakteristik sensori, kimia dan fisik. Analisis karakteristik sensori mengacu pada Sharif et al. (2017) yang menggunakan 20 orang panelis semi terlatih untuk menilai produk menggunakan skala hedonik (skor 1 hingga 5) dari parameter rasa, aroma, warna, tekstur dan penerimaan keseluruhan. Analisis karakteristik kimia yang dilakukan meliputi analisis kadar air dan kadar protein yang mengacu pada AOAC (2005). Analisis karakteristik fisik meliputi parameter hardness, springiness dan cohesiveness yang mengacu pada Aminullah et al. (2020) dengan modifikasi berupa pengaturan kondisi operasi trigger $10 \mathrm{~g}$, deformation 10 $\mathrm{mm}$, speed $2 \mathrm{~mm} / \mathrm{s}$. Sampel pempek dipotong berbentuk silinder dengan diameter $3 \mathrm{~cm}$ dan ketebalan $1,5 \mathrm{~cm}$ yang kemudian diletakkan di bawah probe alat Texture Analyzer. Setelah dioperasikan, probe akan menekan sampel hingga sampel mengalami deformasi. Hasil pengujian akan muncul berupa angka pada layar komputer sebagai data nilai hardness, springiness dan cohesiveness.

Analisis Data. Data yang diperoleh dari analisis karakeristik kimia dan fisik dianalisis secara statistik melalui analisis ragam (ANOVA), sedangkan data yang diperoleh dari analisis karakteristik sensori dianalisa dengan menggunakan statistik non-parametrik melalui metode uji Kruskal-Wallis. Pengolahan data secara statistik menggunakan software SPSS versi 23. Jika terdapat pengaruh nyata dari perlakuan, maka akan dilanjutkan dengan Uji BNT untuk melihat perbedaan pengaruh dari masing-masing perlakuan pada selang kepercayaan 95\% (signifikansi $\mathrm{p}<0,05$ ).

\section{HASIL DAN PEMBAHASAN}

Karakteristik Sensori. Karakteristik sensori pempek yang dianalisis pada penelitian ini diantaranya warna, aroma, rasa, tekstur dan penerimaan keseluruhan. Karakteristik tersebut berkaitan dengan hasil penilaian tingkat kesukaan panelis terhadap produk yang diujikan. Hasil penilaian karakteristik sensori pempek dengan perlakuan variasi penggunaan daging ikan tenggiri dan ikan kiter pada penelitian ini disajikan pada Tabel 2.

Hasil analisis ragam menunjukkan bahwa variasi daging ikan tenggiri dan ikan kiter memberikan pengaruh yang signifikan terhadap warna pempek yang dihasilkan $(\mathrm{p}<0,05)$ dan tidak berpengaruh signfikan terhadap aroma, rasa, tekstur dan penerimaan keseluruhan ( $p>0,05)$. Pempek perlakuan P2 berbeda nyata dengan perlakuan P3 dan P6, dimana perlakuan P2 secara nyata memiliki skor tertinggi yaitu 3,95 (suka) dan perlakuan P6 memiliki skor terendah yaitu 3,10 (agak suka). Berdasarkan hal tersebut diketahui bahwa semakin banyak penggunaan ikan kiter secara signifikan dapat menurunkan kesukaan panelis terhadap warna pempek yang dihasilkan. Hal ini diduga disebabkan oleh pengaruh dari daging ikan kiter yang memiliki daging merah lebih banyak dibandingkan ikan tenggiri, sehingga warna pempek yang dihasilkan cenderung lebih gelap. Rendemen daging merah ikan tenggiri sebesar dari 8,85\% (Maulid \& Nurilmala 2015), sedangkan daging merah ikan kiter cenderung lebih tinggi yaitu 9\% (Chakrabarti \& Gupta 2000). Suman \& Joseph (2013) menjelaskan bahwa proses pemasakan akan menyebabkan denaturasi dari mioglobin pada daging merah dan denaturasi yang diinduksi oleh panas ini menghasilkan pigmen globin hemichrome (ferrihemochrome) yang menyebabkan warna coklat kusam pada produk olahan daging yang dimasak. 
Berdasarkan hal tersebut pempek yang dibuat dari ikan kiter yang memiliki daging merah lebih banyak dapat menurunkan kesukaan panelis terhadap warna pempek yang dihasilkan. Ikan dengan rendemen daging putih yang lebih besar akan menghasilkan warna pempek yang lebih terang dan cenderung lebih disukai oleh panelis.

Tabel 2. Karakteristik sensori pempek dengan variasi daging ikan tenggiri dan ikan kiter

\begin{tabular}{clcccc}
\hline Sampel & Warna & Aroma & Rasa & Tekstur & Penerimaan keseluruhan \\
\hline P1 & $3,72 \mathrm{ab}$ & 3,53 & 3,65 & 3,38 & 3,75 \\
P2 & $3,95 \mathrm{a}$ & 3,83 & 3,90 & 3,70 & 3,95 \\
P3 & $3,48 \mathrm{~b}$ & 3,65 & 3,73 & 3,73 & 3,67 \\
P4 & $3,72 \mathrm{ab}$ & 3,77 & 3,72 & 3,78 & 3,77 \\
P5 & $3,70 \mathrm{ab}$ & 3,78 & 3,78 & 3,83 & 3,93 \\
P6 & $3,10 \mathrm{c}$ & 3,83 & 3,57 & 3,68 & 3,75 \\
\hline
\end{tabular}

Keterangan:

- Skor 1 (sangat tidak suka), skor 2 (tidak suka), skor 3 (agak suka), skor 4 (suka), skor 5 (sangat suka)

- Angka diikuti huruf yang berbeda pada kolom yang sama menunjukkan perbedaan yang signifikan berdasarkan Uji BNT pada taraf $\alpha=5 \%$

Penggunaan variasi daging ikan tenggiri dan ikan kiter secara statistik tidak berpengaruh signifikan terhadap aroma, rasa, tekstur dan penerimaan keseluruhan dari pempek yang dihasilkan. Nofitasari et al. (2015) melaporkan hal yang sama dimana pempek dari perlakuan penggunaan jenis ikan yang berbeda, yaitu ikan gabus, ikan lele dan ikan cakalang, tidak berpengaruh terhadap aroma dan rasa yang dihasilkan. Aroma pempek lebih dipengaruhi oleh penggunaan bawang putih, sedangkan rasa lebih dipengaruhi oleh penggunaan garam pada formulasi pempek. Bawang putih diketahui memiliki kandungan minyak atsiri yang menimbulkan aroma volatil dengan sensasi harum dan juga dapat memberikan rasa gurih pada makanan (Srihari et al. 2015). Hasil uji sensori parameter rasa pada penelitian ini tidak berpengaruh signifikan oleh penggunaan variasi daging ikan. Parameter rasa pempek diduga lebih dipengaruhi oleh perbedaan jumlah penggunaan garam pada formulasi, sedangkan pada penelitian ini menggunakan garam dengan jumlah yang sama untuk setiap perlakuan. Talib \& Marlena (2015) menyatakan penambahan garam pada adonan pempek berpengaruh pada rasa enak pempek yang dihasilkan. Selain itu asam amino yang terkandung pada daging ikan menghasilkan senyawa yang memberi cita rasa setelah proses pemasakan.

Parameter tekstur pempek pada penelitian ini tidak berpengaruh signifikan oleh penggunaan variasi daging ikan tenggiri dan ikan kiter. Parameter tekstur ini diduga lebih dipengaruhi faktor lain seperti variasi jumlah penggunaan tepung tapioka yang digunakan, sedangkan pada penelitian ini menggunakan tepung tapioka dalam jumlah yang sama untuk setiap perlakuan. Semakin banyak tapioka yang digunakan cenderung menghasilkan tekstur pempek yang keras, dan apabila terlalu sedikit maka tekstur pempek akan terlalu lembut. Pembentukan tekstur tersebut disebabkan oleh adanya gelatinisasi pati saat proses perebusan. Proses perebusan bertujuan agar pati mengalami proses gelatinisasi sehingga granula pati mengembang dan protein terdenaturasi. Pengembangan granula pati ini disebabkan molekul-molekul air melakukan penetrasi ke dalam granula dan terperangkap dalam susunan molekul-molekul amilosa dan amilopektin (Simpson 2012).

Karakteristik Kimia. Karakteristik kimia pempek yang diuji adalah kadar air dan kadar protein, sedangkan karakteristik fisik yang diuji pada penelitian ini adalah tekstur yang meliputi hardness, cohesiveness dan springiness. Hasil pengukuran karakeristik fisik dan kimia pempek dalam penelitian ini disajikan pada Tabel 3 . 
Tabel 3. Karakteristik kimia dan fisik pempek dengan variasi daging ikan tenggiri dan ikan kiter

\begin{tabular}{cccccc}
\hline \multirow{2}{*}{ Sampel } & $\begin{array}{c}\text { Kadar air }(\%, \\
\text { bb) }\end{array}$ & Kadar protein $(\%, \mathrm{bk})$ & Hardness $(\mathrm{gf})$ & $\begin{array}{c}\text { Karakteristik fisik } \\
\text { Cohesiveness }\end{array}$ & $\begin{array}{c}\text { Springiness } \\
(\mathrm{mm})\end{array}$ \\
\hline P1 & 64,96 & 19,81 & 626,50 & 1,17 & 13,37 \\
P2 & 64,43 & 18,90 & 484,17 & 1,18 & 13,07 \\
\hline P3 & 64,02 & 18,80 & 463,17 & 1,45 & 15,23 \\
P4 & 64,37 & 19,89 & 405,83 & 0,84 & 9,43 \\
P5 & 63,92 & 21,60 & 427,17 & 1,81 & 15,27 \\
P6 & 66,87 & 21,99 & 360,00 & 1,78 & 15,87 \\
\hline
\end{tabular}

Kadar air pempek pada penelitian ini berkisar dari 63,92\% hingga 66,87\%, dan kadar protein berkisar dari $18,80 \%$ hingga $21,99 \%$. Nilai hardness pempek dengan variasi daging ikan tenggiri dan ikan kiter pada penelitian berkisar dari 360,00 gf hingga 626,50 gf, nilai cohesiveness berkisar dari 0,84 hingga 1,81, dan nilai springiness berkisar dari $9,43 \mathrm{~mm}$ hingga $15,87 \mathrm{~mm}$. Hasil analisis ragam menunjukkan bahwa variasi penggunaan ikan tenggiri dan ikan kiter tidak berpengaruh signifikan terhadap karakteristik tekstur dan kimia pempek $(\mathrm{p}>0,05)$.

Variasi penggunaan daging ikan tenggiri dan ikan kiter dalam penelitian ini tidak mempengaruhi karakteristik kimia pempek yang meliputi kadar air dan kadar protein. Hal ini diduga kadar air dan kadar protein dari masing-masing ikan tidak berbeda jauh. Maulid \& Nurilmala (2015) melaporkan kadar air dan kadar protein ikan tenggiri berturut-turut sebesar 76,58\% dan 18,56\%. Jacoeb et al. (2018) melaporkan kadar air dan kadar protein daging ikan kiter berturut-turut sebesar $72,47 \%$ dan $17,41 \%$. Kadar air pempek diduga dipengaruhi oleh jumlah bahan tambahan lain yang digunakan seperti air es. Semakin banyak air yang ditambahkan maka kadar air pempek juga akan semakin tinggi. Talib \& Marlena (2015) menambahkan bahwa pempek yang dibuat menggunakan ikan air tawar akan cenderung memiliki kadar air yang lebih tinggi dibandingkan pempek yang dibuat menggunakan ikan air laut. Kadar protein pempek juga dapat dipengaruhi oleh faktor lain yaitu jumlah tepung tapioka yang digunakan dan lama waktu perebusan. Rofiq \& Ernawati (2017) melaporkan bahwa semakin banyak tepung tapioka yang digunakan secara signifikan menurunkan kadar protein pempek yang dihasilkan, dan semakin lama proses perebusan secara signifikan dapat menurunkan kadar protein pempek. Hal ini dimungkinkan karena semakin lama proses perebusan maka semakin banyak juga protein ikan yang mengalami denaturasi dan larutnya protein larut pada daging ikan (sarkoplasma) ke dalam air rebusan.

Karakteristik Fisik. Karakteristik fisik yang diuji pada penelitian ini adalah sifat tekstur dari produk yang meliputi hardness, cohesiveness dan springiness. Hardness digunakan dalam menggambarkan ketidakhalusan remah dari suatu produk. Nilai hardness yang tinggi menandakan produk cenderung semakin keras (Haliza et al. 2017). Tabel 3 menunjukkan bahwa penggunaan variasi ikan tenggiri dan ikan kiter tidak berpengaruh signifikan terhadap parameter hardness pempek. Hal ini diduga dipengaruhi oleh kadar air dari ikan tenggiri dan ikan kiter yang tidak berbeda jauh. Setyowati \& Nisa (2014) melaporkan bahwa salah satu faktor yang mempengaruhi parameter hardness pada pempek adalah kadar air dalam bahan. Semakin tinggi kadar air bahan maka nilai hardness akan rendah.

Cohesiveness adalah area tekan dari kompresi kedua hingga kompresi pertama. Cohesiveness merupakan tingkatan bahan saat dapat dihancurkan oleh gerakan mekanis (Indiarto et al. 2012). Cohesiveness merupakan atribut tekstur mekanis yang berhubungan dengan tingkat makanan dapat terdeformasi sebelum hancur (Di Monaco et al. 2008). Tabel 3 menunjukkan bahwa penggunaan variasi daging ikan tenggiri dan ikan kiter tidak berpengaruh signifikan terhadap parameter cohesiveness pempek. Cohesiveness pempek diduga lebih dipengaruhi oleh penggunaan tepung tapioka yang berkaitan dengan 
kadar amilopektin. Iswara et al. (2019) menjelaskan bahwa sifat amilopektin memiliki daya rekat yang tinggi, oleh karena itu semakin tinggi kadar amilopektin dari tepung yang digunakan cenderung meningkatkan kekompakan (cohesiveness) dari suatu produk.

Springiness atau elastisitas merupakan waktu pemulihan antara waktu gigitan pertama dengan gigitan kedua. Nilai springiness menggambarkan kemampuan produk untuk dapat kembali ke posisi awal setelah kompresi pertama hingga saat kompresi kedua akan dimulai (Indiarto et al. 2012, Haliza et al. 2017). Tabel 3 menunjukkan bahwa penggunaan variasi daging ikan tenggiri dan ikan kiter tidak berpengaruh signifikan terhadap parameter springiness pempek. Hal ini diduga dipengaruhi oleh jumlah rendemen daging putih ikan tenggiri dan ikan kiter yang tidak berbeda jauh (pada ikan kiter sebesar 91\% dan ikan tenggiri sebesar 92\%). Daging putih pada ikan mengandung protein miofibril yang berkontribusi terhadap elastisitas produk (Chakrabarti \& Gupta 2000, Maulid \& Nurilmala 2015). Faktor lain yang lebih mempengaruhi springiness dari pempek adalah kadar amilopektin dari tepung yang digunakan. Aminullah et al. (2020) melaporkan pempek dari ikan lele dengan peningkatan jumlah tepung tapioka yang digunakan secara signifikan meningkatkan elastisitas pempek yang dihasilkan. Simpson (2012) menjelaskan bahwa pati dengan kadar amilopektin yang tinggi mampu menghasilkan produk dengan sifat gel yang tidak kaku, sedangkan pati dengan amilosa yang tinggi justru menghasilkan gel yang kaku pada produk.

Perlakuan Terbaik. Pemilihan perlakuan terbaik pada penelitian ini selain ditinjau dari hasil analisis karakteristik sensori, kimia dan fisik, juga dilihat dari sisi ekonomi yaitu biaya bahan baku yang dikeluarkan. Ardianti (2015) menyebutkan bahwa biaya bahan baku harus dijadikan pertimbangan dalam usaha kuliner atau makanan. Rahmawati (2019) menambahkan karena biaya bahan baku secara signifikan akan mempengaruhi harga pokok produksi suatu barang. Semakin ekonomis biaya bahan baku maka semakin tinggi juga keuntungan yang didapatkan. Biaya bahan baku pada penelitian ini dihitung berdasarkan harga beli di pasaran dan disesuaikan dengan pemakaian bahan berdasarkan formulasi yang digunakan pada penelitian ini (Tabel 1). Hasil perhitungan biaya bahan baku pembuatan pempek dengan variasi penggunaan daging ikan tenggiri dan ikan kiter disajikan pada Tabel 4.

Tabel 4. Biaya bahan baku pempek untuk setiap perlakuan

\begin{tabular}{lccccccc}
\hline \multicolumn{1}{c}{ Bahan baku } & Harga pasar & \multicolumn{5}{c}{ Biaya bahan baku (Rp) } \\
& $(\mathrm{Rp})$ & $\mathrm{P} 1$ & $\mathrm{P} 2$ & $\mathrm{P} 3$ & $\mathrm{P} 4$ & $\mathrm{P} 5$ & P6 \\
\hline Ikan tenggiri (utuh) & $90.000 / \mathrm{kg}$ & 18.000 & 14.400 & 10.800 & 7.200 & 3.600 & - \\
Ikan kiter (utuh) & $35.000 / \mathrm{kg}$ & - & 1.400 & 2.800 & 4.200 & 5.600 & 7.000 \\
Tepung tapioka & $22.000 / \mathrm{kg}$ & 3.300 & 3.300 & 3.300 & 3.300 & 3.300 & 3.300 \\
Garam & $12.000 / \mathrm{kg}$ & 96 & 96 & 96 & 96 & 96 & 96 \\
Air & $19.500 / 19 \mathrm{~L}$ & 154 & 154 & 154 & 154 & 154 & 154 \\
\hline \multicolumn{1}{c}{ Total } & & 21.550 & 19.350 & 17.150 & 14.950 & 12.750 & 10.550 \\
\hline
\end{tabular}

Berdasarkan perhitungan biaya total bahan baku diketahui bahwa biaya total bahan baku untuk pembuatan pempek sesuai formulasi penelitian berkisar dari Rp 10.550 hingga Rp 21.550. Semakin banyak pemakaian ikan tenggiri maka biaya bahan baku pembuatan pempek akan semakin tinggi dan semakin banyak pemakaian ikan kiter maka biaya bahan baku akan semakin rendah. Hasil analisis karakteristik kimia dan fisika tidak dijadikan pertimbangan dalam pemilihan perlakuan terbaik karena secara statistik perlakuan yang diberikan tidak memberikan pengaruh yang signifikan. Namun hasil analisis karakteristik sensori yaitu parameter warna dapat dijadikan pertimbangan dalam menentukan perlakuan terbaik yang dikaitkan dengan biaya total bahan baku pembuatan pempek. Pada Tabel 2 dapat dilihat bahwa sampel perlakuan P2 memang memiliki rata-rata nilai tertinggi kesukaan panelis terhadap warna pempek, namun bila dibandingkan dengan sampel perlakuan P4 dan P5 secara statistik tidak menunjukkan perbedaan yang signifikan, atau tingkat kesukaan panelis terhadap warna pempek perlakuan P2, P4 dan P5 adalah sama. Berdasarkan hasil 
perhitungan biaya total bahan baku sampel P2 memiliki biaya total sebesar Rp 19,350, sampel P4 sebesar Rp 14,950 dan sampel P5 sebesar Rp 12,750. Oleh karena itu, perlakuan terbaik ditentukan pada biaya total bahan baku terendah yaitu sampel P5 (daging ikan tenggiri 40 gram dan ikan kiter 160 gram). Perlakuan P5 dapat direkomendasikan sebagai formulasi yang dengan biaya bahan baku yang ekonomis dan memiliki karakteristik sensori yang disukai konsumen.

\section{KESIMPULAN}

Pempek yang dihasilkan dari variasi penggunaan daging ikan tenggiri dan ikan kiter memiliki karakteristik sensori dengan skor parameter warna yang berkisar dari 3,10 (agak suka) hingga 3,95 (suka); skor parameter aroma berkisar dari 3,53 (suka) hingga 3,83 (suka); skor parameter rasa berkisar dari 3,57 (suka) hingga 3,90 (suka); skor parameter tekstur berkisar dari 3,38 (agak suka) hingga 3,83 (suka); dan skor penerimaan keseluruhan berkisar dari 3,67 (suka) hingga 3,95 (suka). Karakteristik kimia pempek memiliki kadar air yang berkisar dari 63,92\% hingga 66,86\% dan kadar protein berkisar dari 18,80\% hingga 21,99\%. Karakteristik fisik pempek memiliki nilai hardness yang berkisar dari 360,00 gf hingga 626,50 gf; nilai cohesiveness berkisar dari 0,84 hingga 1,81; dan nilai springiness berkisar dari 9,43 mm hingga 15,87 mm.

Variasi penggunaan daging ikan tenggiri dan ikan kiter pada penelitian ini berpengaruh terhadap karakteristik sensori yaitu parameter warna. Pempek perlakuan P2 (ikan tenggiri 160 gram, ikan kiter 40 gram) menghasilkan skor warna tertinggi dengan skor 3,95 (suka). Perlakuan dalam penelitian ini juga tidak berpengaruh terhadap karakteristik fisik pempek yang meliputi hardness, cohesiveness, dan springiness; serta tidak berpengaruh terhadap karakteristik kimia yang meliputi kadar air dan kadar protein. Perlakuan P5 (ikan tenggiri 40 gram, ikan kiter 160 gram) merupakan perlakuan terbaik dari sisi ekonomi dengan biaya total bahan baku sebesar Rp 12.750 .

\section{DAFTAR PUSTAKA}

Alhanannasir, Dasir, and Belasanjaya, D., 2018. Karakteristik Fisik, Aroma Dan Protein Pempek Lenjer Dengan Metode Frekuensi Pencucian Air Es. In: The 8 th University Research Colloquium 2018 Universitas Muhammadiyah Purwokerto. 135-143.

Aminullah, A., Daniel, D., and Rohmayanti, T., 2020. Profil tekstur dan hedonik pempek lenjer berbahan lokal tepung talas bogor (Colocasia esculenta L. Schott) dan ikan lele dumbo (Clarias gariepinus). Jurnal Teknologi \& Industri Hasil Pertanian, 25 (1), 7-18.

AOAC, 2005. Official Methods of Analysis of AOAC International. Washington DC: Association of Official Agricultural Chemistry.

Ardianti, Y., 2015. Overhead Pabrik Terhadap Harga Pokok Produksi Pada. Jurnal Jurusan Pendidikan Ekonomi (JJPE), 5 (1), 1-10.

Chakrabarti, R. and Gupta, S., 2000. Characteristics of gel from the meat of twelve species of fish from Visakhapatnam Coast. Food Technology, 37 (1), 5-7.

Haliza, W., Kailaku, S.I., and Yuliani, S., 2017. Penggunaan mixture response surface methodology pada optimasi formula brownies berbasis tepung talas banten (Xanthosoma undipes K. Koch) sebagai alternatif pangan sumber serat. Jurnal Penelitian Pascapanen Pertanian, 9 (2), 96-106.

Indiarto, R., Nurhadi, B., and Subroto, E., 2012. Kajian karakteristik tekstur dan organoleptik daging ayam asap berbasis teknologi asap cair tempurung kelapa. Jurnal Teknologi Hasil Pertanian, 5 (2), 106-116.

Iswara, J.A., Julianti, E., and Nurminah, M., 2019. Karakteristik tekstur roti manis dari tepung, pati, serat dan 
pigmen antosianin ubi jalar ungu. Jurnal Pangan dan Agroindustri, 7 (4), 12-21.

Jacoeb, A.M., Pradana, G.W., and Nurjanah, N., 2018. Karakteristik asam amino dan jaringan daging ikan barakuda (Sphyraena jello). In: Prosiding Seminar Nasional Ikan ke-8. Bogor: Masyarakat Iktiologi Indonesia, 45.

Karneta, R., Rejo, A., Priyanto, G., and Pambayun, R., 2013. Difusivitas panas dan umur simpan pempek lenjer. Jurnal Keteknikan Pertanian, 1 (1), 131-141.

Maulid, D. and Nurilmala, M., 2015. Dna Barcoding Untuk Autentikasi Produk Ikan Tenggiri (Scomberomorus Sp). Jurnal Akuatika Indonesia, 6 (2), 154-160.

Di Monaco, R., Cavella, S., and Masi, P., 2008. Predicting sensory cohesiveness, hardness and springiness of solid foods from instrumental measurements. Journal of Texture Studies, 39 (2), 129-149.

Nofitasari, N., Badar, and Syarif, W., 2015. Pengaruh penggunaan jenis ikan yang berbeda terhadap kualitas pempek. E-Journal Home Economic and Tourism, 10 (3), 356-369.

Rahmawati, L.D., 2019. Pengaruh Biaya Terhadap Harga Pokok Produksi Pada Perusahaan Manufaktur Sub Sektor Makanan dan Minuman Yang Terdaftar Di Bursa Efek Indonesia (BEI). Assets, 9 (2), 59-72.

Rofiq, M. and Ernawati, 2017. Proporsi penambahan tepung tapioka dan lama perebusan terhadap kualitas pempek ikan belut (Monopterus albus). TEKNOLOGI PANGAN: Media Informasi dan Komunikasi Ilmiah Teknologi Pertanian, 8 (1), 9-16.

Sari, M.O.S.K., Suharno, B., and Rahayu, P., 2016. Kandungan Protein dan Sifat Organoleptik Pempek Ikan Rucah dengan Berbagai Konsentrasi Bawang Putih ( Allium sativum ). In: Prosiding Seminar Nasional Sains dan Entrepreneurship III Tahun 2016. Semarang, 424-431.

Setyowati, W.T. and Nisa, F.C., 2014. Formulasi biskuit tinggi serat (Kajian proporsi bekatul jagung : tepung terigu dan penambahan baking powder). Jurnal Pangan dan Agroindustri, 2 (3), 224-231.

Simpson, B.K., 2012. Food Biochemistry and Food Processing. 2nd Editio. Oxford: Wiley-Blackwell.

Srihari, E., Lingganingrum, F.S., Damaiyanti, D., and Fanggih, N., 2015. Ekstrak Bawang Putih Bubuk Dengan Menggunakan Proses Spray Drying. Universitas Surabaya: Fakultas Teknik Kimia, 9 (2), 62 68.

Sugito, S. and Hayati, S., 2006. Penambahan daging ikan gabus (Ophiocepalus strianus BLKR) dan aplikasi pembekuan pada pembuatan pempek gluten. Jurnal Ilmu-Ilmu Pertanian Indonesia, 8 (2), 147-151.

Suman, S.P. and Joseph, P., 2013. Myoglobin chemistry and meat color. Annual Review of Food Science and Technology, 4 (1), 79-99.

Talib, A. and Marlena, 2015. Karakteristik organoleptik dan kimia produk empek-empek ikan cakalang. Agrikan: Jurnal Agribisnis Perikanan, 8 (1), 50-59. 